\title{
U-Pb geochronology of detrital zircon from Upper Jurassic synorogenic turbidites, Galice Formation, and related rocks, western Klamath Mountains: Correlation and Klamath Mountains provenance
}

\author{
M. Meghan Miller ${ }^{1}$ and Jason B. Saleeby \\ Division of Geological and Planetary Sciences, California Institute of Technology, Pasadena
}

\begin{abstract}
Synorogenic turbidites of the Upper Jurassic Galice Formation overlie a variety of basement terranes within the western Klamath Mountains along the Oregon - California border, including the early Late Jurassic ophiolite assemblages, ensimatic arc deposits, and sedimentary terranes. U-Pb analyses of 68 multiple grain fractions from 11 samples of detrital zircon support the correlation of Galice Formation on these various basement terranes, although some new complexities in provenance are revealed. With one exception, upper intercept ages range from $1509_{-3}^{+3}$ to $1675_{-8}^{+8} \mathrm{Ma}$. Least squares regression of all fractions yields an upper intercept age of $1583 \pm 1 \mathrm{Ma}$, indicating the importance of an ultimately continental, recycled, and generally wellmixed sedimentary source. Early Mesozoic lower intercept ages range between $183_{-2}^{+2}$ and $263_{-3}^{+4}$ and average $215 \pm 1 \mathrm{Ma}$. Results from Galice cover on sedimentary basement show significantly older 2.1 Ga Precambrian component, however, that may be locally derived from pre-Late Jurassic basement rocks that are rich in recycled sedimentary debris. Existing isotopic data from older, zircon-bearing Klamath units further indicate that Galice detritus was derived from immediate source terranes within the Klamath Mountains. Reworking of fragile limestone clasts from the biogeographically distinctive eastern Klamath terrane (McCloud Limestone) into Galice Formation substrate also supports early paleogeographic ties between terranes. Thus the tectonic setting of the Late Jurassic Nevadan orogeny in the Klamath Mountains is tightly constrained by original paleogeographic ties between subterranes of the western belt and by provenance ties to terranes to the east. Ultimately continent-derived clastic debris and other distinctive tracers were recycled within this long-lived ensimatic convergent margin system.
\end{abstract}

\section{Introduction}

The western North American Cordillera experienced a protracted and complex history of active margin accretion throughout much of the Paleozoic and early Mesozoic. Inboard of the Cretaceous Pacific Rim complex, critical components of the accretionary orogen were assembled by late Middle Jurassic time [Monger, 1984; Saleeby, 1983]. Nevertheless, the paleogeographic setting of the Late Jurassic Nevadan orogeny in California and southern Oregon has been the subject of some debate. Controversy centers on the paleogeographic and paleotectonic origins of island arc and related terranes, whether more than one subduction zone existed at any single time, and the polarity of subduction offshore western North America during this time interval. In the Klamath Mountains, the record of accretionary processes that acted during Jurassic time is little disturbed by younger magmatism and deformation. Thus it is an ideal area to establish

\footnotetext{
${ }^{1}$ Now at Department of Geology, Central Washington University, Ellensburg.
}

Copyright by the American Geophysical Union.

Paper number 95JB00761.

0148-0227/95/95JB-00761/\$05.00 paleogeographic relations during late Middle and Late Jurassic orogenesis [e.g., Snoke, 1977; Harper and Wright, 1984].

Upper Jurassic synorogenic turbidites of the Galice Formation, Klamath Mountains (Figure 1), form part of a regionally extensive belt of coeval volcaniclastic and chertlithic-rich epiclastic rocks that were deposited in widespread basinal settings within the Cordilleran accretionary orogen. The belt extends from Alaska to the Sierra Nevada and has been discussed in detail by McClelland et al. [1992]. In the western U.S., this belt includes the Lummi Group that overlies the Fidalgo ophiolite, San Juan Islands [Garver, 1988], the Lonesome and Coon Valley Formations in the Blue Mountains of Oregon [Brooks and Vallier, 1978; Dickinson and Thayer, 1978], the Mariposa Formation of the Sierra Nevada Foothills [Bogen, 1984] and basal strata of the northern Great Valley Sequence, and the Knoxville Formation, which unconformably overlies the Coast Ranges ophiolite in California [Jones, 1975]. The Galice Formation was deposited on and is intercalated with diverse lithotectonic substrates (Figures 1 and 2). On the basis of differences in depositional basement, parts of the Galice Formation belong to differing subterranes [Blake et al., 1985]. Nevertheless, they are generally accepted to be paleogeographically related. If differing parts of the Galice Formation belong to a single lithostratigraphic unit, then the strata form a sequence that overlaps the differing basement terranes. Establishing such an overlap relation 


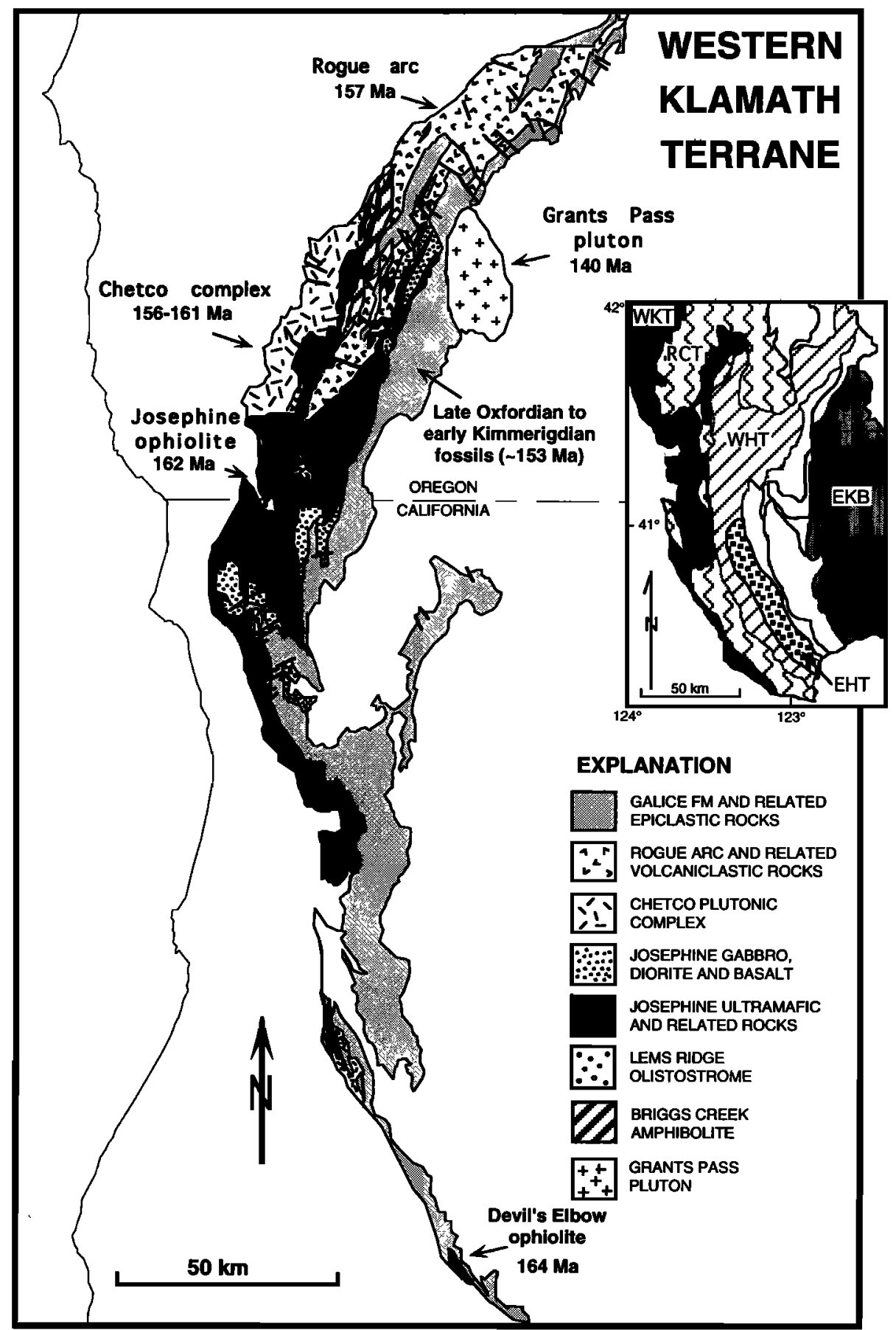

Figure 1. Geologic map of the Western Klamath terrane and part of the adjacent northern Coast Ranges. Map is simplified from Smith et al. [1982], Wagner and Saucedo [1987], Fraticelli et al. [1987], and Jayko and Blake [1986]. Radiometric ages are from Saleeby [1984, 1987] and Wyld and Wright [1988]; fossil age is from Imlay [1961]. Inset shows distribution of some older terranes in the southwestern Klamath Mountains, northern California. Abbreviations are WKT, Western Klamath terrane (detailed in this figure); RCT, Rattlesnake Creek Terrane; WHT, western Hayfork terrane; EHT, Eastern Hayfork terrane; EKB, eastern Klamath belt, which includes the Trinity ophiolite, Yreka terrane, and eastern Klamath terrane.

further constrains early Late Jurassic paleogeographic relations between the various basement terranes and the tectonic setting of the Nevadan orogeny [e.g., Harper, 1983; Snoke, 1977; Yule and Saleeby, 1993].

This paper presents new isotopic data for detrital zircon populations from the Galice Formation and its lithostratigraphic equivalents in the Klamath Mountains. The samples come from widespread locations where strata rest on different basement terranes (Figure 1). We use distinctive but similar detrital zircon populations within various parts of the Galice Formation, together with the provenance of major framework constituents in sandstone and biostratigraphic and regional stratigraphic relations, to support correlation among the Upper Jurassic turbidites. The presence of an early to mid- 


\section{DEPOSITIONAL SETTINGS OF THE GALICE FORMATION}

North

ROGUE RIVER:

Rogue arc \&

Chetco complex

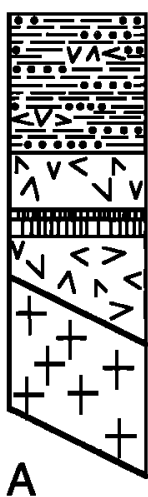

Galice Formation

Buchia concentrica

8. Minifusus:

middle Oxfordian

Rogue arc

$150 \pm 2 \mathrm{Ma}$ dacite dikes basaltic andesite

$157 \pm 2$ Ma tuffs

plagioclase porphyry

Chetco complex

156-161 Ma constructed on RCT \& Preston Peak equivalents

Garcia, 1982

Pessagno \& Blome, 1990

Saleeby, 1984

Yule \& Saleeby, 1993
SMITH RIVER:

Josephine ophiolite

\section{LEMS RIDGE: \\ Olistostrome}

S. FORK TRINITY

RIVER: Devil's

Elbow ophiolite

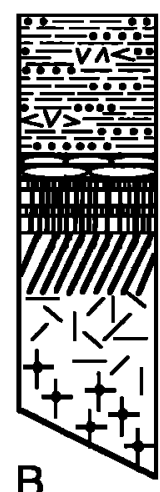

Harper, 1983, 1984

Pessagno \& Blome, 1990

Saleeby et al., 1982

Saleeby, 1987

gabbro

peridolite
Galice Formation Buchia concentrica \& Mirifusus: middle Oxfordian

Josephine ophiolite Callovian chert Pillow basalt $162 \pm 1$ Ma plagiogranite sheeted dikes

Figure 2. Depositional settings of the Galice Formation. Lithotectonic relationships of different basement subterranes within the Western Klamath terrane are shown. Abbreviations are the same as in Figure 1.
Proterozoic component of radiogenic lead further suggests an ultimate source of older continental crust for some of the detritus preserved within these primarily ensimatic rocks. Finally, we summarize isotopic data for detrital zircon from some older terranes within the Klamath Mountains, in order to evaluate their possible roles as intermediate source terranes for the old zircon component in the Western Klamath terrane.

\section{Geologic Setting}

The Western Klamath terrane (of Silberling et al. [1987]; formerly western Jurassic belt of Irwin [1966]) forms the westernmost and structurally lowest imbricate fault slice within the Klamath Mountains. It comprises four principal lithotectonic assemblages (Figure 2): (1) the Chetco complex (156 - $161 \mathrm{Ma}, \mathrm{U}-\mathrm{Pb}$ zircon [Yule and Saleeby, 1993]) and Rogue arc (150 - $157 \mathrm{Ma}$ [Saleeby, 1984]), an Upper Jurassic volcano-plutonic ensimatic arc association; (2) the Josephine ophiolite (162 Ma [Harper et al., 1994]), a complete oceanic crustal sequence that evolved in a back arc setting [Harper, 1980, 1984]; (3) the Briggs Creek amphibolite which records a polyphase metamorphic and structural history that likely culminated with thrusting of the Josephine ophiolite during the Nevadan orogeny [Harper et al., 1990; Harper and Harding, 1986]; and (4) Oxfordian-Kimmeridgian turbidite strata of the Galice Formation $(-157-152 \mathrm{Ma}$, based on the timescale of Harland et al. [1990]; -157 - $150 \mathrm{Ma}$ based on local biostratigraphy and geochronology [Pessagno and Blome, 1990]), which is interfingered with volcaniclastic rocks of the Rogue arc and rests depositionally on pillow lavas of the Josephine ophiolite. All but the amphibolite are areally widespread in the northern part of the terrane; only fragments of the ophiolite and epiclastic rocks exist farther to the south, together with fragmentary serpentinite matrix melange (Figure 1).

Rocks that form depositional and structural basement to the Galice Formation and its suggested equivalents include volcanic arc strata of the Rogue Formation [Garcia, 1979, 1982]; ophiolitic rocks of the coeval Josephine, Devil's Elbow, and Coast Ranges complexes [Bailey et al., 1970; Harper, 1984; Hopson et al., 1981; Wright and Wyld, 1986]; Jurassic sedimentary deposits of the Lems Ridge olistostrome (summarized in Figure 2) [Harper et al., 1985; Ohr, 1987]; and in the south, serpentinite matrix melange units of variable age and origins [Jayko and Blake, 1986; Wyld and Wright, 1988]. The Upper Jurassic Galice strata provide a potential link between differing basement terranes. The Galice Formation was deformed and metamorphosed to low greenschist or subgreenschist facies during the Late Jurassic Nevadan orogeny. The age of deformation is bracketed by the presence of Buchia concentrica (late Oxfordian-early Kimmeridgian) within the deformed rocks [Imlay, 1961] and Buchia rugosa (Kimmeridgian) within the overlying, undeformed basal Great Valley Sequence [Jones, 1975]. These biostratigraphic constraints agree well with zircon-derived radiometric ages for Nevadan deformation (157 - $150 \mathrm{Ma}$ [Wright and Fahan, 1988]), although ${ }^{40} \mathrm{Ar} /{ }^{39} \mathrm{Ar}$ data on metamorphic assemblages yield younger (Cretaceous) ages [Hacker et al., 1993]. The argon data may record denudation instead, consistent with the occurrence of depositional outliers of the Great Valley Sequence on the western Klamath Mountains. Integration of detailed radiolarian biostratigraphic studies from the Galice Formation and regional geochronometry have been used to refine the Late Jurassic timescale [Pessagno and Blome, 1990].

\section{Stratigraphic Relations of the Galice Formation}

Stratigraphic and compositional monotony together with structural complexity have hampered detailed stratigraphic and structural studies of the Galice Formation. Structural thickness exceeds several kilometers; ubiquitous cleavage, isolated fold hinges, localized overturned bedding, bedding-parallel faulting, and lack of distinctive stratigraphic markers preclude 
determining original stratigraphic thickness [Cashman, 1988]. The Galice Formation is predominately composed of thinly interbedded argillite and fine-grained lithic-rich wacke in partial Bouma sequences that represent distal or dilute turbidites. Tens of meters of volcaniclastic-rich wacke and tuffaceous argillite at the base of the formation are succeeded up section by hundreds of meters (structural thickness) sedimentary-lithic rich wacke and siliceous argillite. Sparse chert-pebble conglomerate horizons are present but lack the lateral continuity needed to make the distinctive marker horizons.

At its type locality along the Rogue River, the Galice Formation overlies and interfingers with volcaniclastic strata of the Rogue arc (Figure 2a) [Garcia, 1979]. Although there the contact is obscured by poor exposure, a depositional relationship is supported by the similarity in age of both units and the laterally persistent intercalation of volcanic and epiclastic debris on many scales. In places, however, evidence for disruption of the contact is observed, and the depositional contact is locally faulted [Park-Jones, 1988]. The type Galice Formation is dated by the presence of the index fossil Buchia concentrica, which indicates a late Oxfordian to early Kimmeridgian age (D. L. Jones, as given by Harper [1983]). Using radiolarian biostratigraphy to augment the megafossil data base, Pessagno and Blome [1990] consider the basal Galice Formation to be mid-middle Oxfordian in age at its type locality.

To the south, along the Oregon-California border (Figure 1), volcaniclastic strata of the basal Galice Formation overlie pillow basalt of the Josephine ophiolite (Figure $2 b$ ) and grade upward into typical fine-grained chert-lithic-rich turbidites [Harper, 1983, 1984]. The depositional contact between the pillow lavas and the turbidites is well exposed in polished exposures along the Smith River, although locally the orientation of dikes relative to bedding suggests that some seafloor faulting and tilting predated deposition of the hemipelagic and epiclastic cover [Harper, 1984]. Thus the Galice Formation may also depositionally overlie deeper levels of the ophiolite. The underlying Josephine ophiolite is $162 \mathrm{Ma}$ [Harper et al., 1994] or late Callovian [Pessagno and Blome, 1990]. The Galice Formation is middle Oxfordian to Kimmeridgian, as indicated by the presence of Buchia concentrica [Imlay, 1961] and the first occurrence of Mirifusus [Pessagno and Blome, 1990]. Radiolaria indicate that deposition spanned the Oxfordian-Kimmeridgian boundary based on the last occurrence of Xiphostylus [Pessagno and Blome, 1990]. In addition, radiolarian provincialism indicates a change in latitude from central Tethyan to northem Tethyan to southern Boreal over a time interval of about 5 m.y. [Pessagno and Blome, 1990].

South of the Smith River area, the Galice Formation overlies Jurassic deposits of the Lems Ridge olistostrome (Figures 1 and 2) [Harper et al., 1985; Ohr, 1987; Ohr et al., 1986]. This unit consists of olistostromal pebbly mudstone, interbedded pelagic rocks, and sandstone that rest on gabbroic basement; Middle Jurassic radiometric ages suggest that the Rattlesnake Creek terrane forms depositional basement [ $\mathrm{Ohr}$, 1987]. Blocks within the pebbly mudstone include gabbro, pillow lavas, scoria, metamorphic rock fragments, and metavolcanic rocks. On the basis of age and geochemistry, most blocks within the olistostrome are thought to have been derived from the easterly Rattlesnake Creek and western Hayfork terranes, although in some cases, geochemical affinity of mafic lavas may suggest that the Josephine ophiolite provided blocks to the basin [Ohr, 1987]. The sequence is depositionally overlain by epiclastic rocks of the Galice Formation [Ohr, 1987]. The Galice Formation here is contiguous with strata in the Smith River area and is presumably of the same age. The underlying olistostromal and intercalated sedimentary rocks are interpreted as rift edge deposits that were shed from the eastern margin of the Josephine basin onto the attenuated, rifted substrate of the Rattlesnake Creek terrane and onto "spillover" lavas of the Josephine ophiolite, which marked a ridge-transform junction within a growing intra-arc rift basin [Ohr, 1987].

Farther south, along the South Fork of the Trinity River, the Western Klamath terrane comprises a thin structural sliver containing the Devil's Elbow ophiolite remnant, serpentinite matrix melange, and epiclastic and volcaniclastic strata (Figure 2) [Wyld and Wright, 1988]. The ophiolite remnant contains a well-developed sheeted-dike complex, thin and discontinuous pillow lavas, and ophiolitic debris breccia; cogenetic plagiogranite has been dated as $164 \mathrm{Ma}$ (U-Pb zircon [Wright and Wyld, 1986]) and thus is correlative with the Josephine ophiolite. The chert-rich epiclastic strata depositionally overlie the Devil's Elbow ophiolite and have been correlated with the Galice Formation on the basis of lithology, structural and stratigraphic relations, and broad age constraints [Wyld and Wright, 1988]. Serpentinite matrix melange intrudes the terrane bounding thrust fault and represents a remobilized, structurally lower unit derived from the western rifted margin of the basin, which was composed of lithologies like those of the eastward Rattlesnake Creek terrane [Wyld and Wright, 1988]. Subsequent faulting has tectonically kneaded younger blocks of the Galice Formation into the melange [Wyld and Wright, 1988].

Age constraints on the epiclastic rocks are bracketed by the $164 \mathrm{Ma}$ zircon age on the ophiolitic substrate [Wright and Wyld, 1986] and an overprinting metamorphic aureole related to a $147 \mathrm{Ma}$ pluton and thus broadly span the age range of Galice strata to the north [Wyld and Wright, 1988]. Precambrian inheritance $(1.7 \mathrm{Ga}$ upper intercept age [Wright and Wyld, 1986]) in zircon from cogenetic plagiogranite implies that the ophiolite floored a marginal basin that was rifted across older Klamath terranes containing ancient zircon. These relations further support an intra-arc origin within the Klamath accretionary province. In addition, such an unusual inheritance pattern in ophiolitic rocks could only have occurred during the initial stage of rifting, when the spreading center was developed across the older terranes. Thus the 164 Ma crystallization age dates the inception of rifting within the marginal basin at this location [Wright and Wyld, 1986].

\section{Provenance}

The Galice Formation consists of a structurally thickened succession of fine-grained siliceous turbidites, lesser volcaniclastic strata, and sparse interstratified conglomeratic deposits. Structural complexity and lack of lithofacies variation have precluded detailed assessment of patterns in the stratigraphic succession. Nevertheless, vertical variations in composition of sandstone to some extent reflect original variation within the stratigraphic section; wherever the depositional base of the unit is exposed, it is volcaniclasticrich and varies upward to chert- and sedimentary-lithic dominated sandstone throughout most of the succession. The volcaniclastic units are present where the Galice depositionally overlies the Josephine ophiolite or where it is 
interfingered with volcaniclastic strata of the westward Rogue arc.

Most wacke within the Galice Formation contains abundant reworked chert, other sedimentary lithic grains, and feldspar. Minor heavy mineral constituents in the feldspathic lithic-rich wacke include zircon, tourmaline, apatite, muscovite, and lesser chromian spinel, biotite, garnet, sphene, and blue amphibole [Harper, 1983]. A lesser volcaniclastic source is also regionally distributed [Harper, 1983; Wyld and Wright, 1988]. Both volcanic- and sedimentary-rich compositions point to a source comprised of older ensimatic terranes of the Klamath Mountains [Harper, 1983]. Paleocurrent data from both the basal volcanic-lithic-rich wackes and stratigraphically higher sedimentary-lithic-rich rocks generally confirm an eastward derivation [Harper, 1984; ParkJones, 1988; Snoke, 1977]. Some juvenile volcaniclastic interbeds may be derived from the Rogue arc or similar units [Wyld and Wright, 1988] which formed to the west.

\section{Detrital Zircon Populations}

Zircon is a robust detrital mineral and thus is a useful tracer for ultimate crystalline source terranes. Grain roundness gives a qualitative measure of sedimentary recycling, and of age, insofar as older sources generally have undergone more erosion cycles. Zircon color partly results from radioactive damage and thus may also serve as a qualitative measure of zircon age or uranium concentration. Isotopic compositions of radiogenic lead in zircon allow ready recognition of an old component. Younger components are difficult to characterize in the presence of very old lead components, due to swamping of the younger component by nonlinear variations in isotopic ratios with time as well as the fact that radiogenic lead concentrations are relatively low for the younger component. Detrital zircon yields provenance information, and multigrain fractions, like those discussed here, yield average provenance ages for mixed sedimentary populations. Similarly, intercept ages reflect mixed components. Thus intercept ages do not date a crystalline source terrane but may imply an isotopic average of mixed crystalline sources. The geochronology of the mixed population provides an isotopic fingerprint expressed as an age that allows comparisons between zircon populations from different sedimentary units. This paper, then, discusses intercept ages as fingerprint dates for comparison between populations and for reference to possible source terranes.

In order to characterize and compare source terranes, we analyzed 68 fractions from 11 zircon samples of Galice Formation sandstone for isotopic concentrations of uranium and lead. The 11 samples were collected at representative geologic settings of the Galice Formation where it overlies four differing basement terranes: the Rogue arc, the Josephine ophiolite, the Lems Ridge olistostrome, and the Devil's Elbow ophiolite (Table 1). The samples were collected from over 250 km along strike.

All samples were purified using standard mineral separation techniques and hand picked to $99.9 \%$ purity. With one exception, zircon separates from all samples consist of highly heterogeneous populations. The diverse populations were subdivided into size fractions and hand sorted into subpopulations of different color and grain morphology (Table 1). Colors vary from clear and colorless to ruby red, giving a qualitative measure of radioactive damage related to age and initial uranium concentration. Grain morphology varies from euhedral and highly angular, implying first-cycle sediment from a crystalline source, to well rounded and frosted, indicating multistage reworking through multiple intermediate sedimentary cycles. Freshly broken surfaces were present on grains of all morphologies and result from the sample crushing process. In addition to hand-sorted populations, composite fractions (purified but otherwise unsorted) in the 62 to $80 \mu \mathrm{m}$ size range were run for most samples to ascertain average isotopic composition and allow comparison between samples. One sample (M86-5, Table 1, discussed below) that was collected from a tongue of volcaniclastic strata within the Galice Formation where it overlies the Rogue arc contained more homogeneous populations of clear broken and euhedral grains. In all three size splits from this sample, the few grains that were rounded and darker were hand sorted from the euhedral populations and run as separate fractions.

\section{Isotopic Results}

Isotopic results from the 68 zircon fractions were as highly heterogeneous as their grain color and morphology implied. No discernible patterns in heterogeneity between samples from differing substrate emerged, with one exception, the Lems Ridge sample (Tables 1 and 2). Great age dispersion of differing fractions within samples was achieved by hand sorting, although end-member populations were only imperfectly resolved, as is typical in multigrain analyses.

\section{Old Zircon Component}

Excluding the sample from the Lems Ridge olistostrome, upper intercept ages from the Galice Formation samples range from $1509 \mathrm{Ma}$ to $1675 \mathrm{Ma}$; taken collectively the intercept is $1583 \pm 1$ (Table 2, Figure 3). The formal error on the fingerprint "age" reflects the statistical stability of a large number of analyzed fractions and should not be taken as the possible age variation within the source province, as discussed in some detail above. The old component is generally best approximated by dark-colored, well-rounded populations (Table 1). The relatively narrow range of intercept ages implies a well-defined average isotopic composition for the older component of these samples. The oldest ${ }^{207} \mathrm{~Pb} / 206 \mathrm{~Pb}$ age isolated in a single fraction is $2079 \mathrm{Ma}$ (Table 1), giving a minimum for the oldest isotopic age component in that fraction. Thus the early Proterozoic average intercept discussed above (1583 $\mathrm{Ma}$ ) results from mixing of Archean and younger Proterozoic components. A similar mixing relationship has been documented for intercept ages from many units in western North America (summarized by Miller and Saleeby [1991a] and Gehrels and Dickinson [1995]).

The sample from the Galice Formation where it overlies the Lems Ridge olistostrome has a distinctly older isotopic profile. The upper intercept age is $2153_{-15}^{+14} \mathrm{Ma}$, and several analyzed fractions from this sample plot as outliers to the otherwise well defined body of data (Figures $3 c$ and $3 e$ ). These data indicate heterogeneity in the older component that is not present in the other samples. Its more local derivation from terranes of the western Paleozoic and Triassic belt may account for the discrepancy. There, a $2.1 \mathrm{Ga}$ signature, which is relatively unusual in the Klamath province as a whole (with some exceptions; see Wallin [1989]), is present in a quartz arenite from the Eastern Hayfork terrane (Figure 1, inset) sedimentary matrix melange [Miller and Saleeby, 1991b]. The 


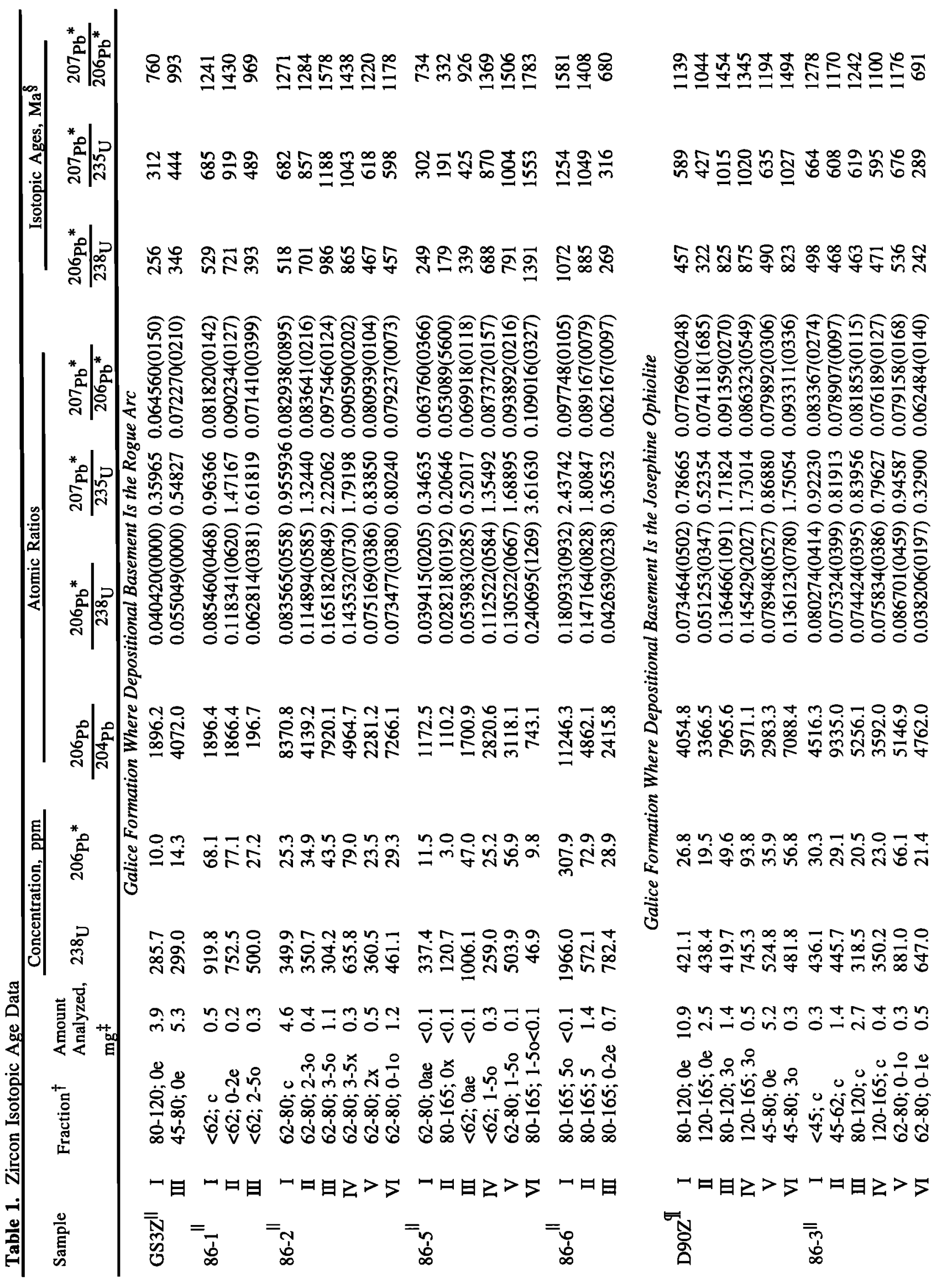




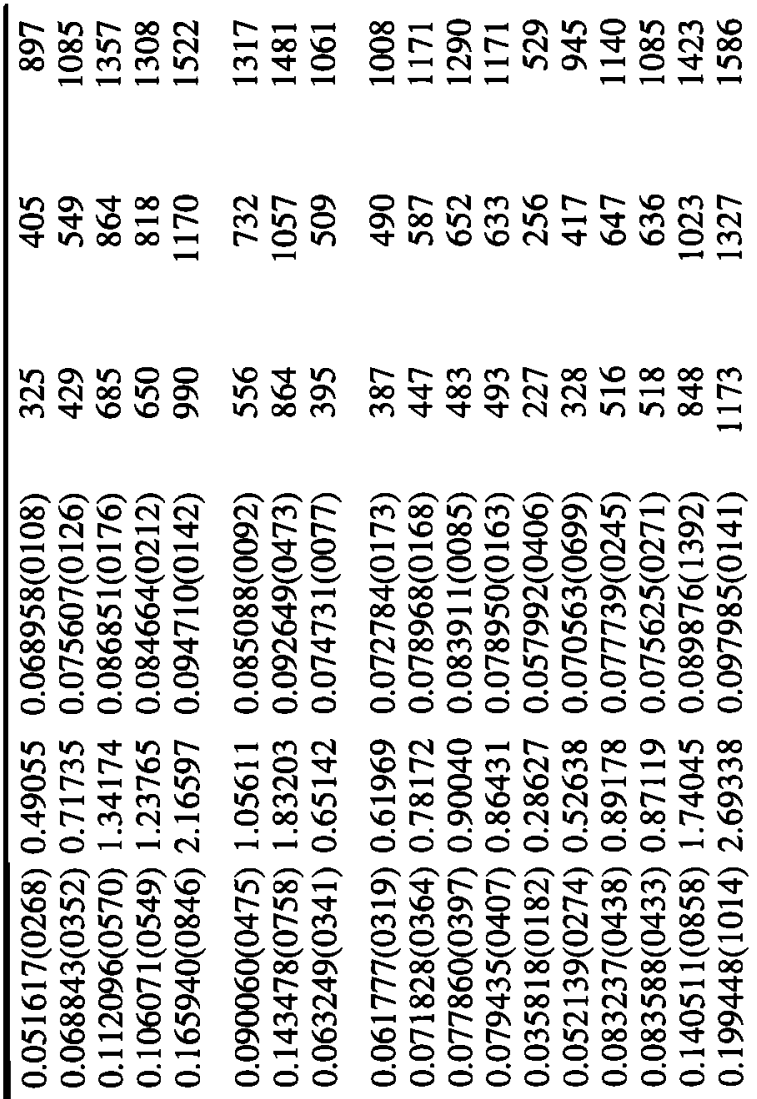

mogan otn-TNtonnam

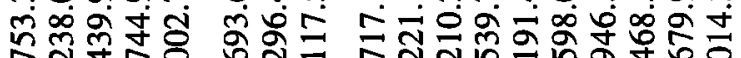

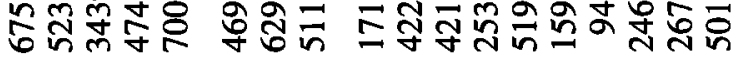

to

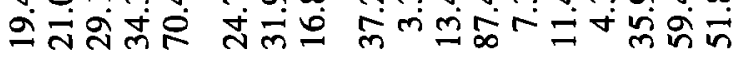

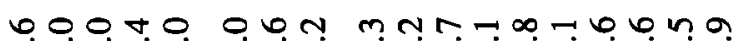

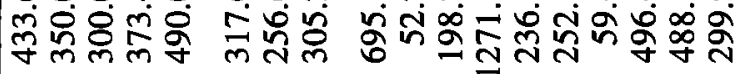

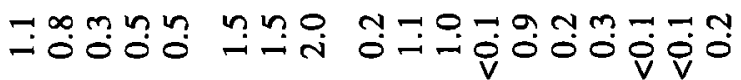

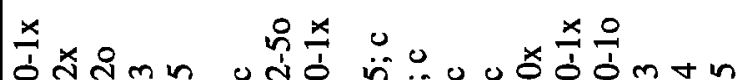

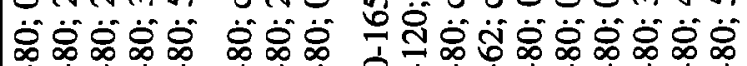
ปิ่

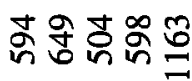

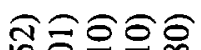

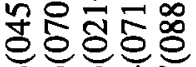

ల్ల

守官市

응ㅇㅇㅇㅇㅇ

훙형영

Ұm $m$

어슈유

ํํㅇํㅡ능

-i -

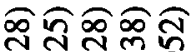

กํํㅇํำ

রํㅠㅇㅠ

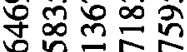

ㄴㅇㅇ응ㅎㅇ응

영영

Trm $\forall n$

守守守守告

$\frac{2}{2}$

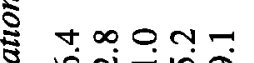

숭

ปั

๓ं

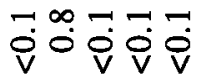

$\because 00 \mathrm{Nm}$

엉

엉ㅎํ ஸ่

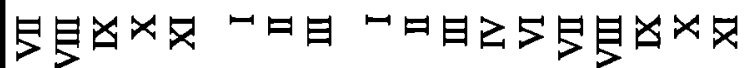

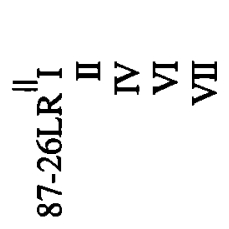

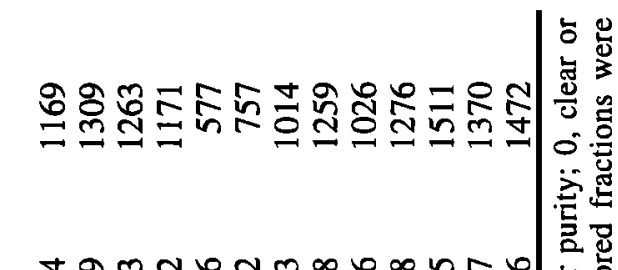

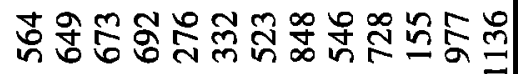

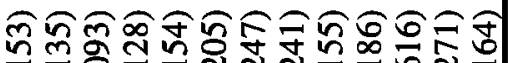

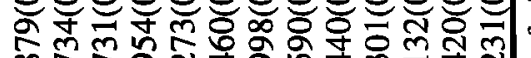

党

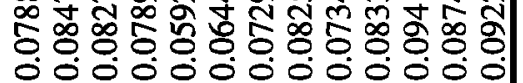

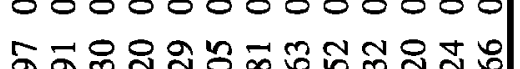

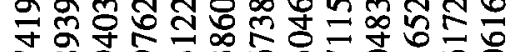

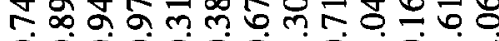

000000ல்

政

\section{政}

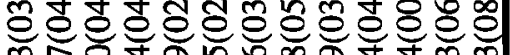

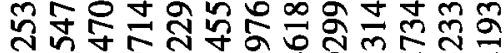

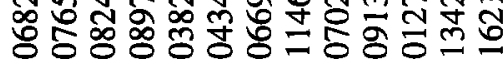

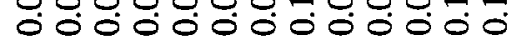

"ूँ

ก t 9 a a m mo

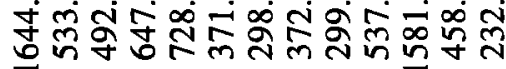

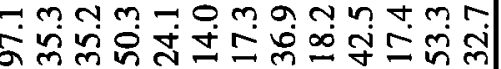

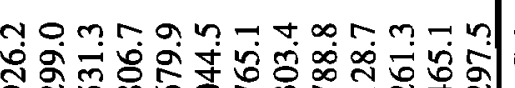

สㅊ

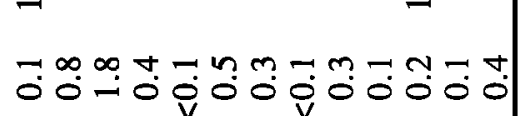

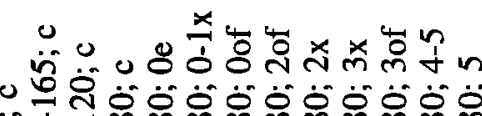

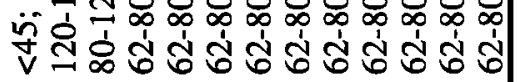

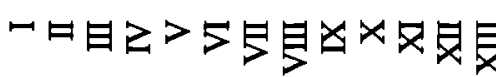

ㅇำ

$\frac{1}{\infty}$

递

空

के

흘 줄

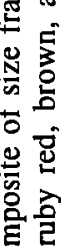

数

공

흔 i

\section{5}

¿ni

语 


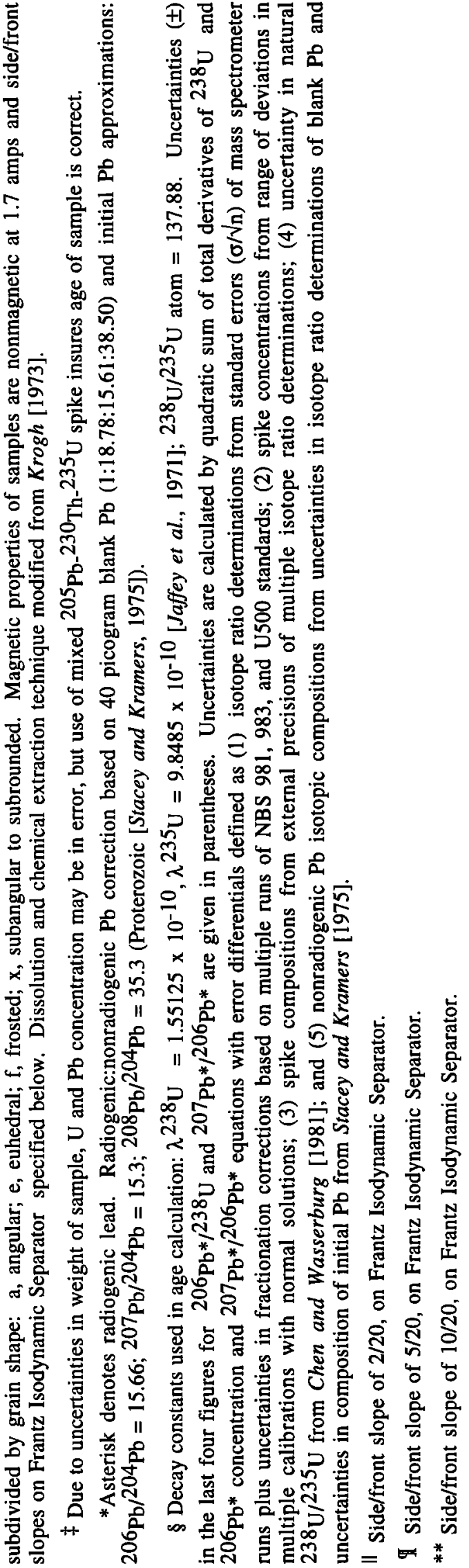

proximity of the relatively isolated source to the Lems Ridge olistostrome and the fact that lithologies represented in the coarse fraction of the olistostrome in part reflect this metasedimentary source support this interpretation.

\section{Young Zircon Component}

Despite the inherent difficulty in isolating the low concentrations of radiogenic lead that represent the younger component, lower intercept ages for Galice Formation samples span a relatively narrow early Mesozoic age range from 183 to $264 \mathrm{Ma}$; the intercept for all 68 fractions is $215 \pm 1 \mathrm{Ma}$ (Table 2). The fractions that best approximate the lower intercept comprise euhedral or angular grains that are colorless or very light pink. Whereas some angular grains were undoubtedly broken during the sample preparation process, these were commonly identified by fragmentary rounded surfaces. Entirely angular grains and euhedral grains are interpreted as first-cycle sediment from immediate crystalline or eruptive sources.

The best resolution of the young component from a U-Pb age came from sample M86-5 (Table 1, Figure 3), which was a richly volcaniclastic, juvenile sample. Extracted zircon was divided into three size fractions. In each fraction were two relatively simple populations: a darker, well-rounded component and a colorless, highly angular component. In the finest fraction $(<62 \mu \mathrm{m})$ the latter population yielded a ${ }^{206} \mathrm{~Pb} /{ }^{238} \mathrm{U}$ age of $179 \mathrm{Ma}$ (Figure 3a). While significant lead loss cannot be ruled out, contamination by some older grains in this detrital sample is certain. In light of this, the discordant date may give a maximum age for the youngest component in the Galice zircon populations with the possible caveat of lead loss. This probable Jurassic component is only somewhat older than the depositional age of the Galice Formation.

\section{Implications}

Detrital zircon populations result from sedimentary cycling and recycling of grains from a wide variety of ultimate crystalline sources. Thus essentially all populations are multicomponent; discordant isotopic ages are expected for multigrain fractions. If the diverse populations are dominated by two distinct age-provenance components, the resulting data array may allow resolution of average upper and lower intercepts that fingerprint the older and younger components, respectively. Such intercept ages are mixing ages in themselves, and ultimate source terranes may actually contain a varied assemblage of crystalline rocks that broadly span these average intercept ages. Thus, while they provide useful isotopic fingerprints for comparison of source areas, source provinces will not perfectly match the intercept age averages. In addition, the concentration of radiogenic lead in Precambrian zircon so far exceeds that from younger, Mesozoic zircon that older components are generally much better defined than younger components.

\section{Discussion}

\section{Correlation and Provenance of the Galice Formation}

The association of Middle and Upper Jurassic arc, ophiolite, and turbidite assemblages within the Klamath Mountains and similar rocks in the Sierra Nevada is thought by many workers 
Table 2. Concordia Intercept Ages for Multifraction Samples From the Galice Formation

\begin{tabular}{|c|c|c|c|c|}
\hline Sample & Depositional Basement & Number of Fractions & Lower Intercept & Upper Intercept \\
\hline GS3Z & Rogue arc & 2 & too few fractions & too few fractions \\
\hline $86-1$ & Rogue arc & 3 & $263_{-3}^{+4}$ & $1675_{-8}^{+8}$ \\
\hline $86-2$ & Rogue arc & 6 & $226_{-1}^{+2}$ & $1594_{-2}^{+3}$ \\
\hline $86-5$ & Rogue arc & 6 & $211_{-1}^{+1}$ & $1626_{-3}^{+4}$ \\
\hline $86-6$ & Rogue arc & 3 & $218_{-1}^{+2}$ & $1588_{-2}^{+2}$ \\
\hline D90Z & Josephine ophiolite & 6 & $183_{-2}^{+2}$ & $1515_{-4}^{+4}$ \\
\hline $86-3$ & Josephine ophiolite & 11 & $206_{-0}^{+1}$ & $1539_{-2}^{+3}$ \\
\hline $86-4$ & Josephine ophiolite & 3 & $234_{-3}^{+2}$ & $1646_{-8}^{+9}$ \\
\hline $87-1$ & Josephine ophiolite & 10 & $225_{-1}^{+1}$ & $1616_{-3}^{+3}$ \\
\hline $87-26$ & Lems Ridge olistostrome & 5 & $244_{-5}^{+5}$ & $2153_{-15}^{+14}$ \\
\hline $87-20$ & Devil's Elbow ophiolite & 12 & $198_{-1}^{+1}$ & $1509_{-3}^{+3}$ \\
\hline Composite & All fractions, above & 68 & $215_{-1}^{+1}$ & $1583_{-1}^{+1}$ \\
\hline
\end{tabular}

to have formed by intra-arc rifting of older terranes within the accretionary belt during late Middle and Late Jurassic time [Snoke, 1977; Saleeby, 1982; Harper et al., 1985; Harper and Wright, 1984; Saleeby et al., 1982; Wright and Fahan, 1988; Yule et al., 1992]. Alternatively, these ophiolitic, arc, and epiclastic assemblages have been considered by some as terranes that are exotic to the accretionary belt, which collided with the continental margin during the Late Jurassic Nevadan orogeny [Day et al., 1985; Moores and Day, 1984; Schweickert and Cowan, 1975; Schweickert et al., 1984]. Some workers attempt to reconcile these two perspectives by invoking different origins for the Klamath and Sierran segments of the Upper Jurassic ophiolite belt [Ingersoll and Schweickert, 1986]. Age relations within the Klamath Mountains establish a very short time interval between generation of western belt assemblages (164 to $\sim 153 \mathrm{Ma}$ ) and their subsequent deformation, together with terranes to the east, during Nevadan orogenesis $(-157$ to $150 \mathrm{Ma}$ [Wright and Fahan, 1988]). In the context of current rates of relative plate motion, only modest tectonic transport could have occurred in the maximum of 5-10 m.y. between ophiolite and arc formation and Nevadan deformation along the western margin of North America. This is consistent with the new data presented here, which show strong depositional ties between the Galice Formation and sources within the Klamath Mountains province.

Biogeographic data that imply migration of the Josephine ophiolite from central Tethyan to northern Tethyan/southern Boreal latitudes during the 5 or so million year time interval [Pessagno and Blome, 1990] are potentially problematic. If modern rates of plate motion were typical during the Jurassic, extremely rapid northward tectonic transport of the Galice depositional basin implied by the change in latitude can be ruled out. Even if we assume a spreading center half-rate over the 5 - 10 m.y. interval that is high relative to those known today, for example $100 \mathrm{~mm} / \mathrm{yr}$, only 500 or $1000 \mathrm{~km}\left(-5-9^{\circ}\right.$ latitude) of poleward transport relative to North America are implied. Furthermore, if spreading were oblique to a N-S direction, this number is a further overestimate.
Alternatively, unusual biogeographic relations may stem from ephemeral paleoclimate conditions. If an unusually wide equatorial zone existed early in Galice history, it may have shrunk relatively quickly during early Late Jurassic time. If coupled with the fortuitous origin of the basin close to the edge of the biogeographic province, biogeographic relations recorded within Galice strata would be misleading. The assumption that Phanerozoic spreading rates are reasonably uniform would support rapid shrinking of the equatorial zone rather than anomalously fast tectonic transport.

The Galice samples collectively represent a coherent data set that strengthens the existing correlation between widespread exposures within the $300-\mathrm{km}$-long belt of the Upper Jurassic synorogenic turbidites (Figure 3). Known similarities in lithology and age are supplemented by morphologically and isotopically similar zircon populations that bring new constraints to the provenance of the belt. This adds a substantial body of data to the evidence that differing substrate terranes were adjacent when the Galice Formation was deposited. Building on the correlation between disparate parts of the Galice Formation, certain other aspects of the Galice depositional system also become apparent.

The isotopic data taken collectively point to a mixed provenance system that is characterized by two distinct components whose isotopic fingerprints are expressed as average intercept ages (Figure 4): an early to mid-Proterozoic average (1583 Ma) and an early Mesozoic average (215 Ma). That these averages also represent mixing may be inferred by analogy, from single crystal work on detrital zircon elsewhere in western North America and from fraction heterogeneity in this study. It is also documented by dispersion within the data set presented here, which indicates a Mesozoic component that may be as young as $179 \mathrm{Ma}$ and a Proterozoic component in excess of $2079 \mathrm{Ma}$ (Figure 3, Table 1). The Proterozoic ages further preclude the interpretation that the Galice Formation formed in an isolated oceanic setting, despite its ensimatic arc and ophiolite basement. The basin must have lain within the reaches of a recycled continental source. Such a recycled sedimentary component is also present within older provinces 

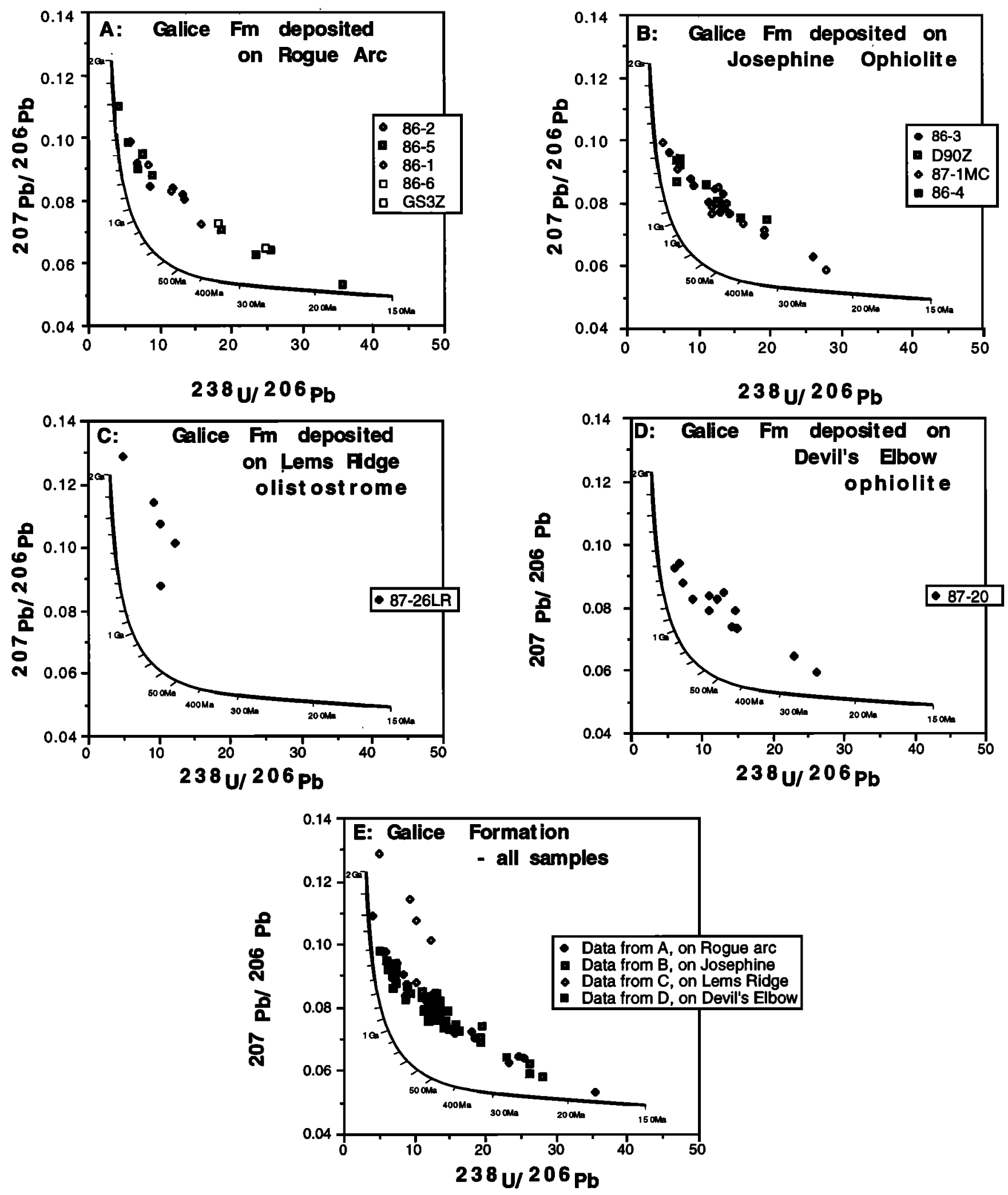

Figure 3. U-Pb isotopic data from lithic-rich wacke of the Galice Formation from the variety of depositional settings that are shown in Figure 2. Concordia is after Tera and Wasserburg [1972]. Data are given in Table 1. Intercept ages for individual samples are given in Table 2. Discordia lines are intentionally omitted, as intercepts merely represent averages of mixed end-member sedimentary components within a sample and do not have specific age significance. 


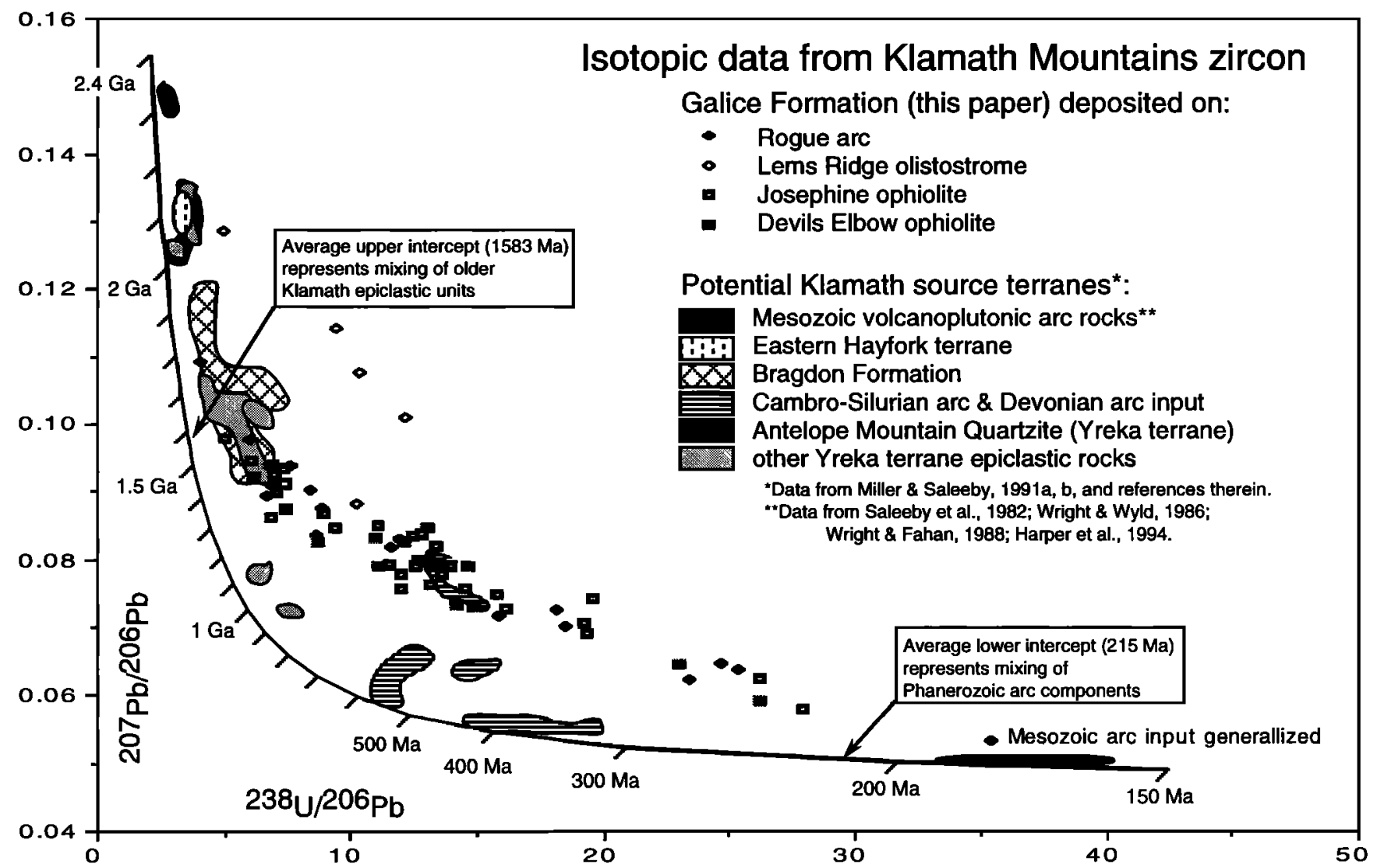

Figure 4. Isotopic values for $\mathrm{U}$ and $\mathrm{Pb}$ in zircon from pre-Late Jurassic rocks of the Klamath Mountains. Fields show areas of data for potential Galice Formation source rocks; superimposed data points show isotopic values for Galice Formation wacke reported here. The discordia lines are intentionally omitted, as intercepts merely represent averages of mixed end-member sedimentary components within a sample and do not have specific age significance.

of the Klamath Mountains [Miller and Saleeby, 1991a, b; Goodge and Renne, 1993] and has been documented by inheritance in zircon from plagiogranite in the Devil's Elbow ophiolite [Wright and Wyld, 1986], indicating that potential source areas lie close at hand within the Klamath Mountains (Figure 4). Such an interpretation was first suggested by provenance studies on the major framework constituents of Galice sandstone [Harper, 1983].

Isotopic studies on zircon presented here confirm that older terranes of the Klamath Mountains formed the source for Galice detritus, as $1.6 \mathrm{Ga}$ mixing ages are typical within the Klamath Mountains [Miller and Saleeby, 1991a, b]. The anomalous 2.1 Ga upper intercept from Galice strata deposited on the Lems Ridge olistostrome extends this interpretation. Whereas some of the analyses from this sample fall within the field of the other samples (Figure 3), there is measurable heterogeneity within the Galice basin that reflects incomplete mixing of sources. Localized potential source areas within the Klamath Mountains have yielded $2.1 \mathrm{Ga}$ upper intercept ages, in particular from the Yreka terrane [Wallin, 1989] and nearby Eastern Hayfork terrane (Figure 1, inset, and Figure 4) [Miller and Saleeby, 1991b]. The abundance of metasedimentary debris in the Lems Ridge olistostrome may have concentrated such older components from the Eastern Hayfork terrane (Figure 1, inset) or reflect a similar localized source. Incomplete mixing of basinal Galice strata further attests to local provenance.
The Galice Formation and its varied substrate formed within an ensimatic convergent margin system that had been active through much of the Phanerozoic. Units within the Klamath province record the sporadic influence of an ultimate continental source terrane. Trench and transform margins form bathymetric barriers to sediment dispersal; thus the Galice basin and its basement terranes must have lain within the western convergent margin of the North American plate.

\section{Implications for the Nevadan Orogeny}

The petrologic, age, and provenance data place very tight constraints on the paleogeographic setting of the Nevadan orogeny in the Klamath Mountains. Late Middle Jurassic contractional deformation was widespread and represents a distinct and earlier orogenic event that was over by at least $161 \mathrm{Ma}$ [Wright and Fahan, 1988]. Very late in the Middle Jurassic, rifting of the arc initiated, forming an intra-arc basin floored by the Josephine ophiolite and its correlatives (162 $164 \mathrm{Ma}$ ) and bordered by the Rattlesnake Creek terrane (Figure 1, inset) and Preston Peak ophiolite that are primarily preserved to the east of and structurally above the Josephine ophiolite. Rifted fragments of these older terranes also sporadically fringe the western edge of the Josephine ophiolite [Wyld and Wright, 1988; Yule et al., 1992] (Figure 5). Rifting was highly oblique and the basin persisted for as much as $-10 \mathrm{~m} . \mathrm{y}$. (based on the $150-142 \mathrm{Ma}$ age of 


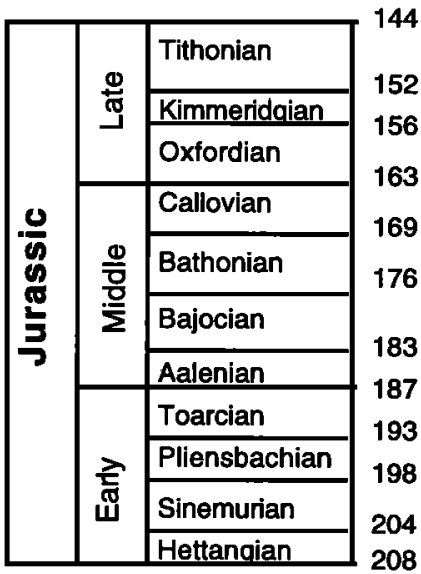

\section{ROGUE ARC \& JOSEPHINE \& LEMS RIDGE CHETCO COMPLEX DEVILS ELBOW OLISTOSTROME OPHIOLITES \\ WESTERN HAYFORK}

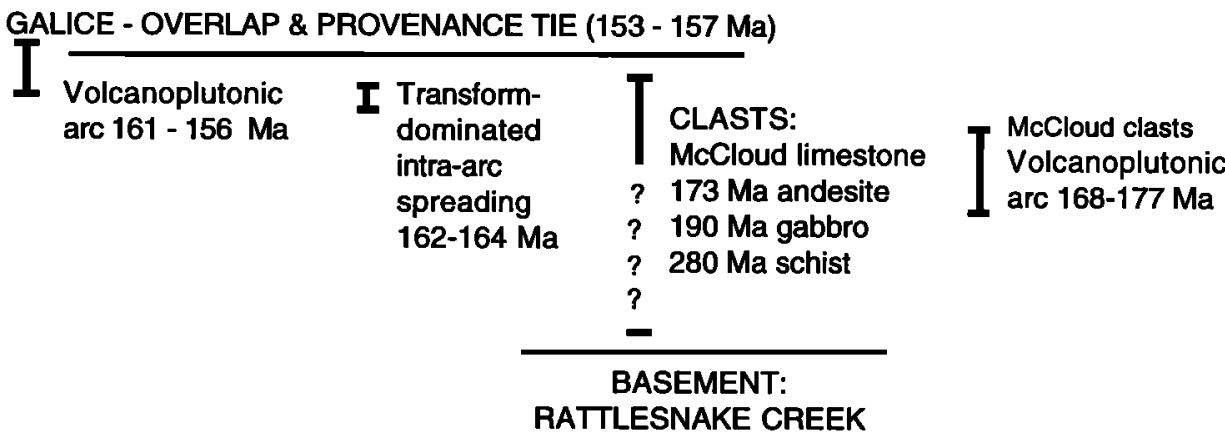

BASED ON: Snoke, 1977; Harper, 1983, 1984; Harper \& Wright, 1984; Saleeby, 1984, 1987; Ohr, 1987; Wright \& Fahan, 1988; Wyld \& Wright, 1988; Yule and Saleeby, 1993.

Figure 5. Summary of age relations and tectonostratigraphic ties of western Klamath subterranes during Jurassic time.

metamorphic aureoles that overprint Nevadan fabrics [Wright and Fahan, 1988]). Contemporaneous and younger arc magmatism was recorded by the Rogue arc volcaniclastic sequence and its plutonic equivalents in the Chetco complex, constraining the back arc geometry of the Josephine basin. Turbidites of the Galice Formation overlap three important basement components, constraining their paleogeographic proximity: the Rogue arc, the Josephine intra-arc to back arc basin, and east side rift edge deposits of the Lems Ridge olistostrome. Chert- and lithic-rich turbidites were derived from older Klamath Mountains terranes which are now primarily preserved to the east. On the basis of paleocurrent data [Park-Jones, 1988; Harper, 1984], the reworked volcaniclastic component is inferred to also have been derived from the east, in contrast to juvenile volcanic debris derived from the contemporaneous, westerly Rogue arc. Combined fossil and radiometric age data tightly constrain basin evolution; Josephine rifting and pelagic sedimentation began near the end of the Callovian; Galice deposition was Oxfordian and Kimmeridgian (Figure 5).

These relations offer three important constraints to the tectonic setting the Nevadan orogeny. Relatively little time was available for tectonic transport of terranes from their sites of origin prior to the Nevadan orogeny. All components involved in Late Jurassic deformation were intrinsic parts of the North American plate margin during the Middle and early Late Jurassic. Thus no major plate boundaries existed between the western Klamath lithotectonic belts. Finally, the overlapping Galice basin was short-lived, was stratigraphically homogeneous, and indicates distinctive provenance ties to eastward lying terranes that ultimately recycled continent-derived debris. Thus Nevadan deformation occurred on the outer edge of the North American plate, where a fringing oceanic convergent margin lay adjacent to the western edge of the continent.

\section{Implications for the Jurassic of Western North America}

Provenance of the Galice Formation has important implications for similar mid-Mesozoic flysch sequences elsewhere in the Cordillera, although several important differences exist. The Galice Formation was deposited over a relatively short and very well defined time interval, similar to the Sierran Mariposa Formation but differing from longerlived basins farther north in the Cordillera [McClelland et al., 1992]. Deposition in most of these basins initiated during the Oxfordian, as it did for the Galice Formation. Elsewhere deposition generally persisted until Cretaceous time, whereas the Galice and Mariposa Formations are tightly constrained to be Oxfordian-Kimmeridgian in age and were deformed during the Late Jurassic. The longer-lived basins to the north were constructed across a major tectonic boundary, between the Intermontane and Insular superterranes [McClelland et al., 1992] and only locally on ophiolitic basement. The northerly sequences were affected by a younger, mid-Cretaceous deformation [Rubin et al., 1990]. The northerly basins formed at the same time and within the same convergent margin system as the Galice and Mariposa basins; they also record sediment influx from adjacent, within-plate sources. But the thickened, transitional or continental depositional basement of the Insular superterrane (Alexander-Wrangellia terranes) may have protected them from the Late Jurassic orogenesis that telescoped the Klamath-Sierran segment of the arc. Some evidence points to continued extension in the northerly basins due to rapidly changing plate kinematic patterns near the Jurassic - Cretaceous boundary [Saleeby and Busby-Spera, 1992]. Consequent to the Nevadan orogeny in California and southern Oregon, magmatism relocated eastward and sedimentation persisted in a more stable forearc setting. It is recorded in the Great Valley Sequence, the Hornbrook Formation, and as outliers of these units that form erosional remnants on the older Klamath Mountains province.

\section{Conclusions}

Detrital zircon potentially traces ultimate continental sources in ensimatic terranes. Complex intermediate marine depositional systems play an important role in sediment recycling and dispersal, however. The absence of old zircon in oceanic rocks is inconclusive; it may reflect bathymetric isolation of structural or volcano-sedimentary basins, rather than geographic separation of arc or oceanic basins from a continent. In contrast, the presence of Precambrian lead in 
Mesozoic terranes provides powerful support of sedimentation patterns that record the influence of a recycled continental source.

The Klamath Mountains represent a microcosm of terranes with affinities to a number of other Cordilleran terranes. Nevertheless, Klamath terranes are relatively undisturbed by postaccretion strike-slip faulting, magmatism, and deformation. Thus they preserve evidence for original paleogeographic relations among terranes and between the terranes and the North American continent. Isotopic studies on detrital zircon from Upper Jurassic synorogenic turbidites of the Galice Formation presented here support a common origin for coeval strata on differing basement terranes. This implies that the western Klamath and adjacent terranes comprise integrated tectonostratigraphic units that accumulated in response to protracted convergence along the western North American plate margin rather than the Jurassic accretion of far traveled and unrelated ensimatic fragments.

Acknowledgments. IBM and the Division of Geological and Planetary Sciences, California Institute of Technology are gratefully acknowledged for supporting Miller on this project. Laboratory work was supported by National Science Foundation grant EAR 87-08266. Greg Harper guided Miller through some of the secrets of Western Klamath terrane geology. Jim Wright has sparked Miller's interest in Klamath Mountains geology in general and in this project in particular. His ideas and his direction to important localities are gratefully acknowledged. Art Snoke, Sandra Wyld, and Doug Yule are also gratefully acknowledged for discussions and insight. Carol Dupuis corrected the data tables and Gerda Smeltzer and Carrie Whitehill assisted with finalizing the figures. Jim Wright and Gary Emst provided helpful reviews.

\section{References}

Bailey, E. H, M. C. Blake, and D. L. Jones, On-land Mesozoic oceanic crust in the California Coast Ranges, U.S. Geol. Surv. Prof. Pap. 700C, C70-C81, 1970.

Blake, M. C., Jr., D. C. Engebretson, A. S. Jayko, and D. L. Jones, Tectonostratigraphic terranes in southwest Oregon, in Tectonostratigraphic Terranes of the Circum-Pacific Region, Earth Sci. Ser., vol. 1, edited by D. G. Howell, pp. 147-157, Circum-Pacific Council for Energy and Mineral Resources, Houston, Tex., 1985.

Bogen, N. L., Stratigraphy and sedimentary petrology of the upper Jurassic Mariposa formation, western Sierra Nevada, California, in Tectonics and Sedimentation Along the California Margin, Bull Soc. of Econ. Paleontol. Mineral. Pac. Sect., 38, 119-134, 1984.

Brooks, H. C., and T. L. Vallier, Mesozoic rocks and tectonic evolution of eastern Oregon and western ldaho, in Mesozoic Paleogeography of the Western United States, Pacific Coast Paleogeography Symposium 2, edited by D. G. Howell and K. A. McDougall, pp. 133146, Pacific Section, Society of Economic Paleontologists and Mineralogists, Los Angeles, Calif., 1978.

Cashnan, S. M., Finite-strain patterns of Nevadan deformation, western Klamath Mountains, California, Geology, 16, 839-843, 1988.

Chen, J.H., and G.J. Wasserburg, The isotopic composition of uranium and lead in Allende inclusions and meteoritic phosphates, Earth Planet. Sci. Lett., 52, 1-15, 1981.

Day, H. W., E. M. Moores, and A. C. Tuminas, Structure and tectonics of the northern Sierra Nevada, Geol. Soc. Am. Bull., 96, 436-450, 1985.

Dickinson, W. R., and T. P. Thayer, Paleogeographic and paleotectonic implications of Mesozoic stratigraphy and structure in the John Day inlier of central Oregon, in Mesozoic Paleogeography of the Western United States, Pacific Coast Paleography Symposium 1, edited by D. G. Howell and K. A. McDougall, pp. 147-161, Pacifjc Section,
Society of Economic Paleontologists and Mineralogists, Los Angeles, Calif., 1978.

Fraticelli, L. A., and J. P. Albers, W. P. Irwin, and M. C. Blake, Jr., Geologic Map of the Redding $1^{\circ} \times 2^{\circ}$ quadrangle, Shasta, Tehama, Humboldt, and Trinity Counties, California, scale 1:250,000, U.S. Geological Survey Open-File Report 87-257, 1987.

Garcia, M. O., Petrology of the Rogue and Galice Formations, Klamath Mountains, Oregon: Identification of a Jurassic island-arc sequence, J. Geol., 87, 29-41, 1979.

Garcia, M. O., Petrology of the Rogue River island-arc complex, southwest Oregon, Am. J. Sci., 282, 783-807, 1982.

Garver, J. I., Fragment of the Coast Range ophiolite and the Great Valley Sequence in the San Juan Islands, Washington, Geology, 16, 948-951, 1988.

Gehrels, G. E, and W. R. Dickinson, Detrital zircon provenance of Cambrian to Triassic miogeoclinal and eugeoclinal strata in Nevada, Am. J. Sci., 295, 18-48, 1995.

Goodge, J. W., and P. R. Renne, Mid-Paleozoic olistoliths in Eastern Hayfork terrane melange, Klamath Mountains: Implications for late Paleozoic - early Mesozoic Cordilleran forearc development, Tectonics, 12, 279-289, 1993.

Hacker, B.R., W. G. Ernst, and M. O. McWilliams, Genesis and evolution of a Permian-Jurassic magmatic arc/accretionary wedge, and reevaluation of terranes in the central Klamath Mountains, Tectonics, 12, 387-409, 1993.

Harland, B. W., R. L. Armstrong, A. V. Cox, L. E. Craig, A. G. Smith, and D. G. Smith, A Geologic Time Scale 1989, pp. 1-263, Cambridge University Press, New York, 1990.

Harper, G. D., The Josephine ophiolite-remains of a late Jurassic marginal basin in northwestern California, Geology, 8, 333-337, 1980.

Harper, G. D., A depositional contact between the Galice Formation and a Late Jurassic ophiolite in northwestern California and southwestern Oregon, Oreg. Geol., 45, 3-7, 1983.

Harper, G. D., The Josephine ophiolite, Geol. Soc. Am. Bult. 95, 10091026, 1984.

Harper, G. D., and D. Harding, Cornment on "Structural study of intraocean thrusting in the Klamath Mountains, Northern California: Implications on accretion geometry" by Mathilde Cannat and Francoise Boudier, Tectonics, 5, 687-692, 1986.

Harper, G. D., and J. E. Wright, Middle to Late Jurassic tectonic evolution of the Klamath Mountains, Califomia-Oregon, Tectonics, 3, 759-772, 1984

Harper, G. D., J. B. Saleeby, and E. Norman, Geometry and tectonic setting of sea-floor spreading for the Josephine ophiolite, and implications for Jurassic accretionary events along the California margin, in Tectonostratigraphic Terranes of the Circum-Pacific Region, Earth Sci. Ser., vol. 1, edited by D. G. Howell, pp. 239-257, Circum-Pacific Council for Energy and Mineral Resources, Houston, Tex., 1985.

Harper, G. D., K. Grady, and J. Wakabayashi, A "Structural study of a metamorphic sole beneath the Josephine ophiolite, Western Klamath terrane, California-Oregon, in Paleozoic and Early Mesozoic Paleogeographic Relations; Sierra Nevada, Klamath Mountains, and Related Terranes, edited by D. S. Harwood and M. M. Miller, Spec. Pap. Geol. Soc. Am., 255, 279-396, 1990.

Harper, G. D., J. B. Saleeby, and M. Heizler, Formation and emplacement of the Josephine ophiolite and the age of the Nevadan orogeny in the Klamath Mountains, Califomia-Oregon: U/Pb zircon and ${ }^{40} \mathrm{Ar} /{ }^{39} \mathrm{Ar}$ geochronology, J. Geophys. Res., 99, 4293-4321, 1994.

Hopson, C. A., J. M. Mattinson, and E. A. Pessagno Jr., Coast Range ophiolite, western California, in The Geotectonic Development of the California, Rubey Vol. I, edited by W. G. Ernst, pp. 307-328, Prentice-Hall, Englewood Cliffs, N. J., 1981.

Imlay, R. W., Late Jurassic fossils from southem California, U.S. Geol. Surv. Prof. Pap., 374D, C1-C53, 1961.

Ingersoll, R. V., and R. A. Schweickert, A plate-tectonic model for Late 
Jurassic ophiolite genesis, Nevadan orogeny and forearc initiation, northern California, Tectonics, 5, 901-912, 1986.

Irwin, W. P., Geology of the Klamath Mountains province, in The Geology of Califomia, edited by E. H. Bailey, Bull. Calif. Div. Mines Geol., 190, 19-38, 1966.

Jaffey, A. H., K.F. Flynn, L. E. Glendenin, W. C. Bentley, and A.M. Essling, Precision measurement of half-lives and specific activities of ${ }^{235} \mathrm{U}$ and ${ }^{238} \mathrm{U}$, Phys. Rev. C Nucl. Phys., 4, 1889-1906, 1971.

Jayko, A. S., and M. C. Blake Jr., Significance of Klamath Rocks between the Franciscan Complex and Coast Range ophiolite, northern California, Tectonics, 5, 1055-1071, 1986.

Jones, D. L., Discovery of Buchia rugosa of Kimmeridgian age from the base of the Great Valley Sequence, Geol. Soc. Am. Abstr. Programs, $7,330,1975$.

Krogh, T. E., A low-contamination method for hydrothermal decomposition of zircon and extraction of $\mathrm{U}$ and $\mathrm{Pb}$ for isotopic age determinations, Geochim. Cosmochim. Acta, 46, 485-494, 1973.

McClelland, W. C., G. E. Gehrels, and J. B. Saleeby, Upper JurassicLower Cretaceous basinal strata along the Cordilleran margin: Implications for the accretionary history of the AlexanderWrangellia-Peninsular terrane, Tectonics, 11, 823-835, 1992.

Miller, M. M., and J. B. Saleeby, Continental detrital zircon in Carboniferous ensimatic arc rocks, Bragdon Formation, eastern Klamath terrane, northern California, Geol. Soc. Am. Bull., 103, 268276, 1991a.

Miller, M. M., and J. B. Saleeby, Permian and Triassic paleogeography of the eastern Klamath arc and Eastern Hayfork subduction complex, Klamath Mountains, California, in Paleozoic Paleogeography of the Western U.S.-II, vol. 67, edited by J. D. Cooper and C. H. Stevens, pp. 643-652, Pacific Section, Society of Economic Paleontologists and Mineralogists, Los Angeles, Calif., 1991b.

Monger, J. W. H., Cordilleran tectonics: A Canadian perspective, Bull. Soc. Géol. Fr., 7, 255-268, 1984.

Moores, E. M., and H. W. Day, Overthrust model for the Sierra Nevada, Geology, 12, 416-419, 1984.

Ohr, M., Geology, Geochemistry and geochronology of the Lems Ridge olistostrome, Klamath Mountains, California, M.S. thesis, 247 pp., State Univ. of New York, Albany, 1987.

Ohr, M., G. D. Harper, and J. E. Wright, Fracture zone origin of the Lems Ridge olistostrome, NW California, Klamath Mountains (abstract), Eos Trans. AGU, 67, 1210, 1986.

Park-Jones, R., Sedimentology, structure and geochemistry of the Galice Formation; sediment fill of a back arc basin and island arc in the western Klamath Mountains, M.S. thesis, 165 pp., State Univ. of New York, Albany, 1988.

Pessagno, E. A., and C. D. Blome, Implications of new Jurassic stratigraphic, geochronometric, and paleolatitudinal data from the Western Klamath terrane (Smith River and Rogue Valley subterranes), Geology, 18, 665-668, 1990.

Rubin, C. M., J. B. Saleeby, D. S. Cowan, M. T. Brandon, and M. F. McGroder, Development of a mid-Cretaceous west-vergent thrust system in the northwestem Cordillera, Geology, 18, 276-280, 1990.

Saleeby, J. B., Polygenetic ophiolite belt of the California Sierra Nevada: Geochronological and tectonostratigraphic development, J. Geophys. Res., 87, 1803-1824, 1982.

Saleeby, J. B., Accretionary tectonics of the North American Cordillera, Annu. Rev. Earth Planet. Sci., 15, 45-73, 1983.

Saleeby, J. B., $\mathrm{Pb} / \mathrm{U}$ zircon ages from the Rogue River area, western Jurassic belt, Klamath Mountains, Oregon, Geol. Soc. Am. Abstr. Programs, 16, 331, 1984.

Saleeby, J. B., Discordance patterns in $\mathrm{Pb} / \mathrm{U}$ zircon ages of the Sierra Nevada and Klamath Mountains (abstract), Eos Trans. AGU, 678 1514-1515, 1987.

Saleeby, J. B., and C. J. Busby-Spera, Early Mesozoic tectonic evolution of the westem U.S. Cordillera, in The Geology of North America, vol. G-3, The Cordilleran Orogen: Conterminous U.S., edited by B. C. Burchfiel, P. W. Lipman, and M. L. Zoback, Geological Society of America, Boulder, Colo., 1992.
Saleeby, J. B., G. D. Harper, A. W. Snoke, and W. E. Sharp, Time relations and structural-stratigraphic patterns in ophiolite accretion, west central Klamath Mountains, California, J. Geophys. Res., 87, 3831-3848, 1982.

Schweickert, R. A., and D. S. Cowan, Early tectonic evolution of the western Sierra Nevada, California, Geol. Soc. Am. Bull., 86, 13291336, 1975.

Schweickert, R. A., D. S. Harwood, G. H. Girty, and R. E. Hanson, Tectonic development of the Northern Sierra terrane-An accreted late Paleozoic island arc and its basement, in Western Geological Excursions, edited by J. Lintz, pp. 1-65, Mackay School of Mines, Reno, Nev., 1984.

Silberling, N. J., D. L. Jones, M. C. Blake Jr., and D. G. Howell, Lithotectonic terrane map of the western conterminous United States, scale 1:2,500,000, U. S. Geol. Surv., Misc. Field Stud. Map MF1874-C, 1987.

Smith, J. G., N. J. Page, M. G. Johnson, B. C. Moring, and R. Gray, Preliminary Geologic Map of the Medford $1^{\circ} \times 2^{\circ}$ quadrangle, Oregon and California, scale 1:250,000, U.S. Geological Survey Open-File Report 82-955, 1982.

Snoke, A. W., A thrust plate of ophiolitic rocks in the Preston Peak area, Klamath Mountains, California, an immature island arc: Petrochemical evidence, Spec. Rep., Calif. Div. Mines and Geol., 129, 67-79, 1977.

Stacey, J. S., and J. D. Kramers, Approximation of terrestrial lead isotope evolution by a two-stage model, Earth Planet. Sci. Lett., 26, 207-211, 1975.

Tera, F., and J. G. Wasserburg, U-Th-Pb systematics in three Apollo 14 basalts and the problem of initial $\mathrm{Pb}$ in lunar rocks, Earth Planet. Sci. Lett., 14, 281 - 304, 1972.

Wagner, D. L. and G.J. Saucedo, Geologic Map of the Weed quadrangle, California, scale 1:250,000, Regional Geologic Map Series, California Division of Mines and Geology, Map No. 4A, 1987.

Wallin, E. T., Provenance of lower Paleozoic sandstones in the eastern Klamath Mountains and the Roberts Mountains allochthon, California and Nevada, Ph.D. thesis, 152 pp., Univ. of Kansas, Lawrence, 1989.

Wright, J. E., and M. R. Fahan, An expanded view of Jurassic orogenesis in the western United States Cordillera: Middle Jurassic (pre-Nevadan) regional metamorphism and thrust faulting within an active arc environment, Klamath Mountains, California, Geol. Soc. Am. Bull., 100, 859-876, 1988.

Wright, J. E., and S. J. Wyld, Significance of xenocrystic Precambrian zircon contained within the southern continuation of the Josephine ophiolite: Devils Elbow ophiolite remnant, Klamath Mountains, northern California, Geology, 14, 671-674, 1986.

Wyld, S. J., and J. E. Wright, The Devils Elbow ophiolite remnant and overlying Galice Formation: New constraints on the Middle to Late Jurassic evolution of the Klamath Mountains, California, Geol. Soc. Am. Bull., 100, 29-44, 1988.

Yule, J. D., and J. B. Saleeby, Highly extended oceanic lithosphere: The basement and wall rocks for the Late Jurassic Rogue-Chetco oceanic arc, Oregon Klamath Mountains, Geol. Soc. Am. Abstr. Programs, 25, 169, 1993.

Yule, D. J., J. B. Saleeby, D. L. Jones, and M. Silk, Correlation of basement terranes across the late Jurassic Josephine inter-arc basin, southwest Oregon and northern California, Geol. Soc. Am. Abstr. Programs, 24, 93, 1992.

M. M. Miller and J. B. Saleeby, Division of Geological and Planetary Sciences, 170-25, California Institute of Technology, Pasadena, CA 91125. meghan@cwu.edu.

(Received July 12, 1994; revised January 30, 1995; accepted February 28, 1995.) 